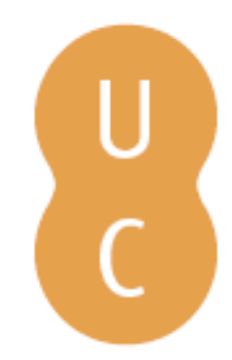

\title{
nombalina
}

\section{Stature-obesity relationships among 11,000 school-aged american indian children}

Autor(es): $\quad$ Himes, John H.; Story, Mary

Publicado por: Imprensa da Universidade de Coimbra

URL

persistente: URI:http://hdl.handle.net/10316.2/38550

DOI: $\quad$ DOI:http://dx.doi.org/10.14195/978-989-26-0773-3_8

Accessed : $\quad$ 26-Apr-2023 15:56:45

A navegação consulta e descarregamento dos títulos inseridos nas Bibliotecas Digitais UC Digitalis, UC Pombalina e UC Impactum, pressupõem a aceitação plena e sem reservas dos Termos e Condições de Uso destas Bibliotecas Digitais, disponíveis em https://digitalis.uc.pt/pt-pt/termos.

Conforme exposto nos referidos Termos e Condições de Uso, o descarregamento de títulos de acesso restrito requer uma licença válida de autorização devendo o utilizador aceder ao(s) documento(s) a partir de um endereço de IP da instituição detentora da supramencionada licença.

Ao utilizador é apenas permitido o descarregamento para uso pessoal, pelo que o emprego do(s) título(s) descarregado(s) para outro fim, designadamente comercial, carece de autorização do respetivo autor ou editor da obra.

Na medida em que todas as obras da UC Digitalis se encontram protegidas pelo Código do Direito de Autor e Direitos Conexos e demais legislação aplicável, toda a cópia, parcial ou total, deste documento, nos casos em que é legalmente admitida, deverá conter ou fazer-se acompanhar por este aviso. 


\section{GROWTH AND \\ MATURATION \\ IN HUMAN BIOLOGY \\ AND SPORTS}

FESTSCHRIFT HONORING ROBERT M. MALINA

BY FELLOWS AND COLLEAGUES

PETER TODD KATZMARZYK MANUEL J COELHO E SILVA

EDITORS 


\title{
STATURE-OBESITY RELATIONSHIPS AMONG SCHOOL-AGED AMERICAN INDIAN CHILDREN
}

\author{
John H. Himes \\ Mary Story
}

Big children are most often tall as well as heavy. Stovitz and colleagues (2008) have demonstrated that the tallest U.S. children also have the highest current body mass index $(\mathrm{BMI})$, and that they are more likely than their shorter peers to become overweight or obese as young adults (Stovitz et al., 2010). American Indian children are among the tallest children in the world (Haas \& Campirano, 2006; Eveleth \& Tanner, 1990), and they have among the highest prevalences of overweight and obesity compared with other children in the United States and elsewhere (Zephier et al., 2006). Nevertheless, there is no information about the relationships between stature and obesity in American Indian children. Because of the elevated risks of obesity and its sequelae in childhood and adulthood, understanding the relationships between growth in stature and excess weight is important for evaluating the growth of American Indian children and for clinical management. Herein, we investigate relationships between stature, BMI and obesity for a large sample of American Indian children, 5- 18 years of age, residing on 12 reservations in the Northern Plains of the United States.

\section{MATERIALS AND METHODS}

The sample children attended 55 schools where at least $50 \%$ of children enrolled were American Indians, and that were located on or adjacent to 12 reservations. The reservations comprise the Aberdeen Area of the Indian Health Service (IHS) and include tribes in the states of lowa, South Dakota, North Dakota and Nebraska. A single welltrained measurement team of 7 individuals collected all data on gender, age, stature and weight during the 2002-2003 school year. For height and weight standardized measurement protocols and equipment were used (Lohman et al., 1988). Data are only reported for American Indian children.

Improbable values for stature and weight were excluded, as were data for children beyond the age cut-offs, leaving a sample of II,099 children (566। boys) 5.0018.99 years of age with complete data. For some analyses children were grouped into whole-year age groups (e.g., 5 yrs $=5.00-5.99$ yr). BMI was calculated as weight $(\mathrm{kg}) /$ stature $(\mathrm{m})^{2}$. Exact percentiles and z-scores for stature, weight and BMI were calculated relative to the CDC 2000 Growth Charts (Kuczmarski et al., 2000). Z-scores or standard deviation scores express the measurements in terms of standard deviation units above or below the reference means for that gender and age, so that a z-score of zero 
corresponds to exactly the reference mean. Overweight was considered as BMI $\geq 85^{\text {th }}$ percentile, and obesity $\mathrm{BMI} \geq 95^{\text {th }}$ percentile following national recommendations (Krebs et al., 2007). Unconditional logistic regression was used to estimate adjusted odds ratios $(\mathrm{OR})$ of variables contributing to overweight and obesity status.

Informed parental consent was obtained according to individual school policies. In some schools, measurements were incorporated into regular health-screening activities. All procedures were approved by the appropriate institutional review boards for tribes and the IHS.

\section{RESULTS}

Table I presents previously unpublished mean stature and BMI for each gender in wholeyear age groups. The means demonstrate the expected patterns of growth in stature and $\mathrm{BMI}$ across this age range.

Table I. Means and standard deviations for stature and BMI of American Indian children

\begin{tabular}{|c|c|c|c|c|c|c|c|c|c|c|}
\hline \multirow[b]{3}{*}{ Age $(y)$} & \multicolumn{5}{|c|}{ Boys } & \multicolumn{5}{|c|}{ Girls } \\
\hline & \multicolumn{3}{|c|}{ Stature $(\mathrm{cm})$} & \multicolumn{2}{|c|}{$\mathrm{BMI}\left(\mathrm{kg} / \mathrm{m}^{2}\right)$} & \multicolumn{3}{|c|}{ Stature $(\mathrm{cm})$} & \multicolumn{2}{|c|}{$\mathrm{BMI}\left(\mathrm{kg} / \mathrm{m}^{2}\right)$} \\
\hline & $\mathrm{N}$ & Mean & SD & Mean & SD & $\mathrm{N}$ & Mean & SD & Mean & SD \\
\hline 5 & 310 & 115.9 & 5.3 & 17.7 & 3.3 & 321 & $1|5|$. & 5.4 & 17.5 & 3.0 \\
\hline 6 & 489 & 121.4 & 5.6 & 18.0 & 3.7 & 459 & 120.1 & 5.6 & 17.7 & 3.2 \\
\hline 7 & 511 & 127.4 & 6.2 & 18.5 & 4.0 & 484 & 126.8 & 5.8 & 18.4 & 3.4 \\
\hline 8 & 507 & 133.3 & 6.0 & 19.4 & 4.4 & 483 & 131.9 & 6.3 & 19.4 & 4.0 \\
\hline 9 & 585 & 138.4 & 6.7 & 20.4 & 4.9 & 529 & 138.7 & 6.5 & 20.3 & 4.3 \\
\hline 10 & 573 & 143.5 & 7.1 & 21.6 & 4.9 & 542 & 144.0 & 7.5 & 21.1 & 5.1 \\
\hline 11 & 533 & 150.0 & 7.7 & 22.9 & 6.0 & 536 & 150.7 & 7.3 & 22.5 & 5.3 \\
\hline 12 & 518 & 156.2 & 8.3 & 23.6 & 6.0 & 479 & 156.2 & 7.1 & 23.2 & 5.3 \\
\hline 13 & 460 & 162.0 & 8.1 & 23.9 & 5.9 & 488 & 160.1 & 6.3 & 24.0 & 5.9 \\
\hline 14 & 381 & 168.2 & 8.1 & 24.3 & 6.2 & 396 & 162.1 & 6.4 & 24.6 & 5.7 \\
\hline 15 & 285 & 172.6 & 7.6 & 24.5 & 6.1 & 270 & 162.9 & 6.2 & 25.4 & 5.9 \\
\hline 16 & 216 & 174.9 & 7.6 & 25.4 & 7.0 & 222 & 164.0 & 6.1 & 25.4 & 5.5 \\
\hline 17 & 203 & 176.0 & 6.9 & 25.6 & 6.4 & 148 & 163.8 & 6.7 & 26.1 & 6.7 \\
\hline 18 & 90 & 178.2 & 7.3 & 25.9 & 6.0 & 81 & 164.2 & 5.6 & 26.6 & 5.8 \\
\hline
\end{tabular}

The age-related patterns of growth in stature and BMI can be better appreciated when presented as z-scores relative to US national data (Figure I). These children clearly have elevated mean z-scores for stature and BMI at every age relative to national data, with mean BMI z-scores substantially higher than stature z-scores. For stature in both genders and for $\mathrm{BMI}$ in boys there is a general trend of decreasing mean z-scores across these ages. The short-term marked rises in mean stature z-scores at about 10 years in boys and 9 
years in girls probably represent relatively advanced maturational timing of the events surrounding adolescence in these children relative to the national reference.

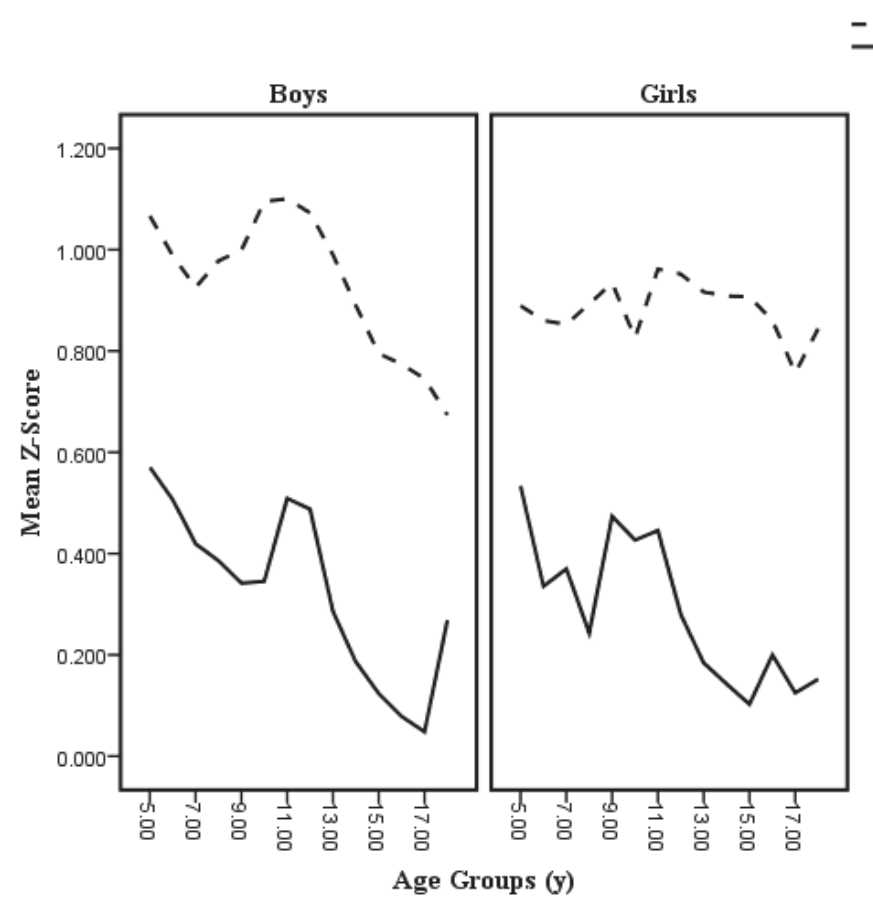

Figure I: Mean z-scores for BMI and stature in boys and girls by whole-year age groups

The age-related patterns of prevalences of overweight and obesity are presented for boys and girls in Figure 2. Prevalences of overweight and obesity are very high in every age group. For boys prevalences peak at II years at 57.2\% and 37.0\% for overweight and obesity, respectively. In girls prevalence of overweight peaks at $51.8 \%$ at 12 years, and for obesity at $29.9 \%$ in the 11 -year age group. 


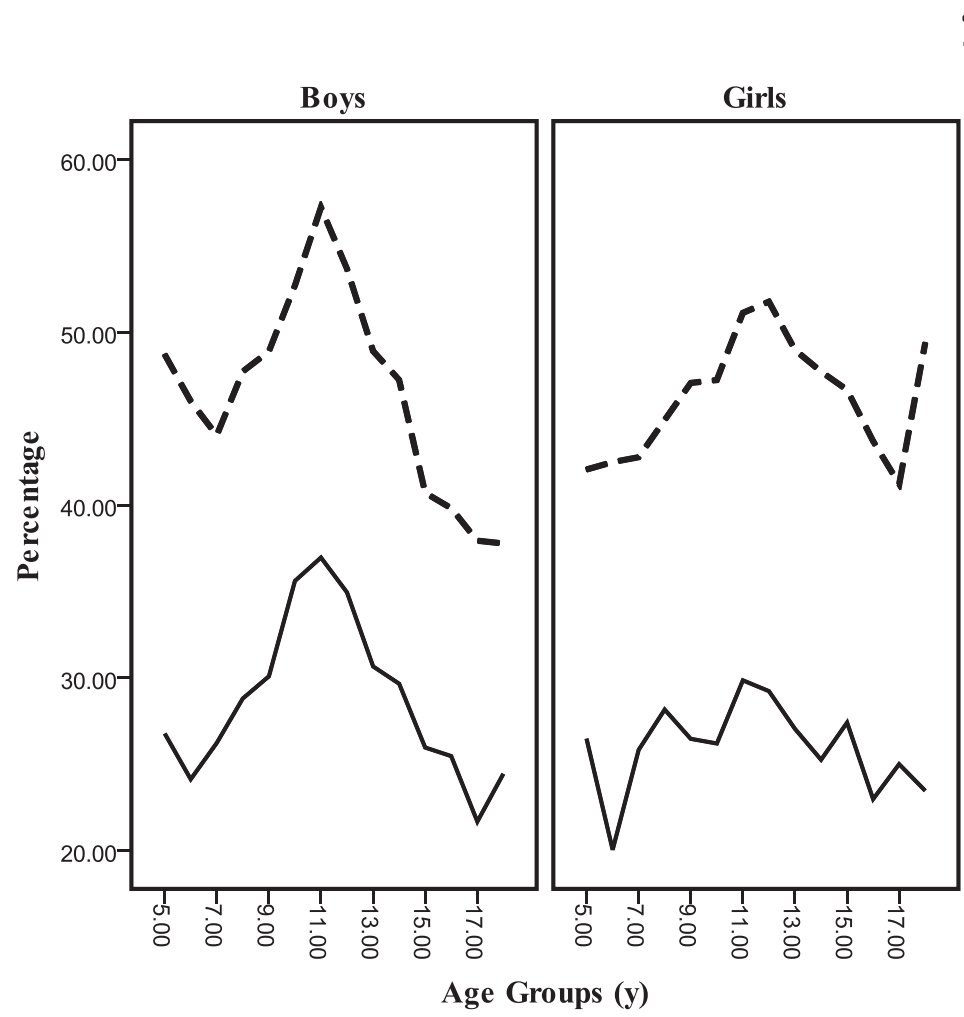

Figure 2: Prevalences of overweight and obesity by whole-year age groups

In these children correlations between stature z-scores and BMI z-scores are $r=0.38$ for boys and $r=0.31$ for girls. The corollary of this substantial positive relationship between stature and BMI can be seen in Figure 3 which presents median BMI Z-scores, plotted for integer categories of stature z-scores. Clearly, taller children have greater BMI, and even for the shortest children, median BMI exceeds zero.

Finally, the results of logistic models investigating determinants of overweight and obesity status based on BMI are presented in Table 2. This analysis translates the associations between BMI and stature into adjusted odds ratios quantifying the risks of overweight and obesity according to categories of stature. Boys are about 15\% more likely than girls to be obese $(\mathrm{OR}=1.16)$, controlling for stature and age, but a similar gender difference does not occur for overweight. There is an increase in adjusted prevalences of overweight and obesity of approximately $2 \%$ per year of age, controlling for gender and stature. 


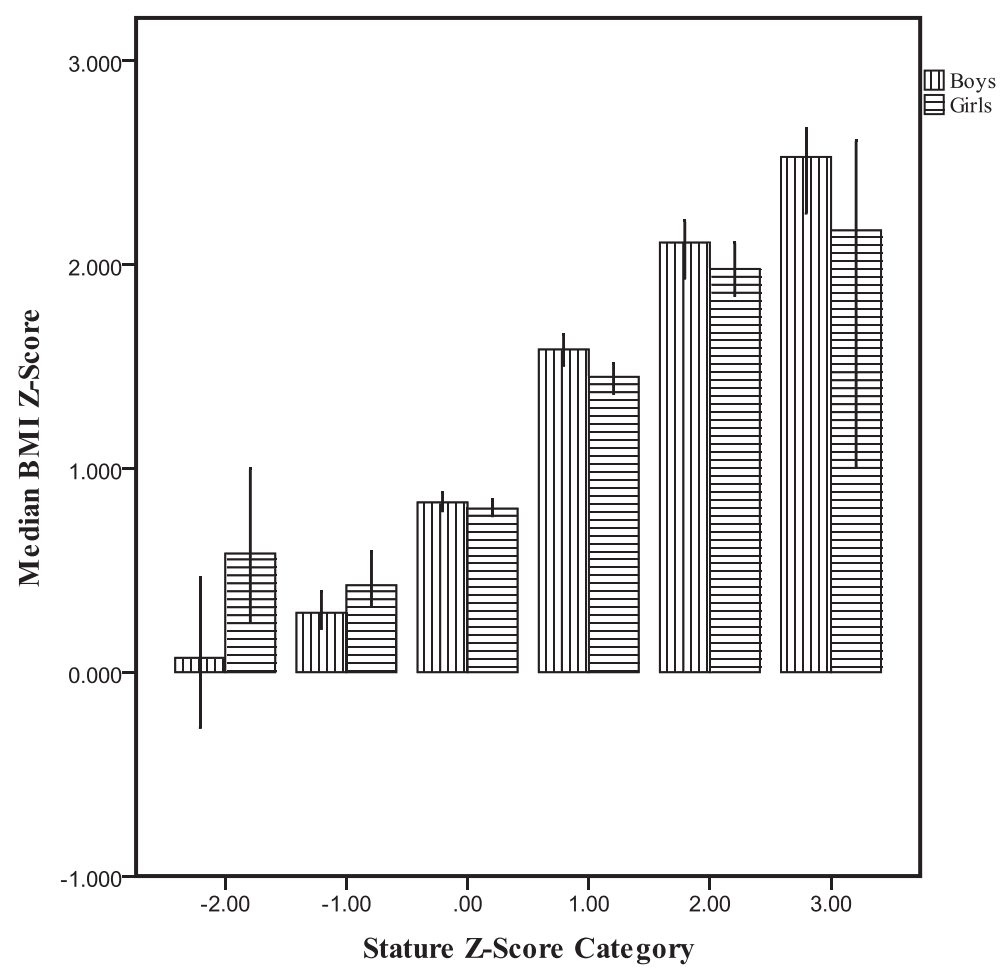

Figure 3: Median BMI Z-Scores $( \pm 95 \% \mathrm{Cl}$ ) by integer stature z-score categories

Integer categories of stature z-scores provide dramatic independent associations with prevalences of overweight and obesity. Compared with the shortest children, those whose stature is close to the median ( $z$-score category ' $O$ ') are still significantly more likely to be overweight $(O R=1.68)$, and risks increase with each subsequently higher stature z-score category, such that children in the highest z-score category $(+3.0)$ have more than II 
times the risk of being overweight. Consecutively higher odds ratios relative to shortest peers are observed for obesity status beginning at stature $z$-score categories of $+1,+2$, and +3 , where adjusted odds ratios are $3.9,9.4$, and 15.5 , respectively.

Table 2: Results from logistic models for overweight and obesity status

\begin{tabular}{|c|c|c|c|c|c|c|}
\hline \multirow[t]{2}{*}{ Variable } & \multicolumn{3}{|c|}{ Overweight } & \multicolumn{3}{|c|}{ Obesity } \\
\hline & OR & $95 \% \mathrm{Cl}$ & Sig. & OR & $95 \% \mathrm{Cl}$ & Sig. \\
\hline $\begin{array}{l}\text { Gender } \\
\text { (boys) }\end{array}$ & 1.05 & $0.97,1.13$ & 0.266 & 1.16 & $1.06,1.26$ & 0.001 \\
\hline Age $(y r)$ & 1.02 & $1.00,1.03$ & 0.007 & 1.03 & $1.01,1.04$ & $<0.00$ I \\
\hline Stat -2 Z & Reference & - & - & Reference & - & - \\
\hline Stat - I Z & 0.83 & $0.56,1.23$ & 0.355 & 0.57 & $0.35,0.92$ & .022 \\
\hline Stat 0 Z & 1.68 & $1.17,2.41$ & 0.005 & 1.37 & $0.89,2.13$ & .154 \\
\hline Stat +1 Z & 4.34 & $2.99,6.29$ & $<0.001$ & 3.90 & $2.51,6.07$ & $<0.00$ I \\
\hline Stat +2 Z & 8.77 & $5.74,13.40$ & $<0.001$ & 9.43 & $5.87,15.16$ & $<0.001$ \\
\hline Stat $+3 Z$ & 11.50 & $5.61,23.59$ & $<0.001$ & 15.48 & $7.70,31.12$ & $<0.001$ \\
\hline
\end{tabular}

\section{DISCUSSION}

Our analyses showed that American Indian school children from the Northern Plains are clearly tall and have high BMI relative to national reference data. In a comparative study of children from around the world, including the current sample, Haas and Campirano (2006) found American Indian youth to be among the very tallest. Historically, American Indians of the Northern Plains were considered tall as children and adults (Wissler, 191 I; Sullivan 1920). An implication of these earlier studies was that the tallness was due primarily to genetic factors. Clearly, nowadays the tallness is associated with overweight and obesity. This finding does not necessarily mean that the tall stature is unrelated to genetic factors, nor that the tallness necessarily results from large gains in BMI or from overweight or obesity status. Because the current data are cross-sectional no conclusions about causality or the direction of causality in the associations between stature and obesity can be made. For example, it may be that the same genes that favor tallness also favor weight gain in an obesogenic environment. Longitudinal study is required to help understand temporal associations between growth in stature and BMI.

The current data are consistent with results in other children indicating positive associations between stature and BMI, and stature and fatness during childhood (Himes and Roche, 1986; Freedman et al., 2004; Stovitz et al., 2008), although these associations 
do not persist in adults. Distinguishing between stature associations with BMI and stature associations with fatness is important because, although BMI is often used as a surrogate for body fatness and obesity status, BMI is really only a measure of body mass and not body fatness per se. Also, BMI includes stature in its denominator, and the squared term for stature may not be the exact exponential to best standardize weight at some ages in childhood, yielding residual associations with stature as an artifact of the formula used (Cole, 1991).

Some of the tallness of American Indian children in our sample is probably due to relatively advanced somatic maturation or growth tempo. As boys approach adolescence they accumulate weight and body fat about two years before they undergo the adolescent spurt in stature (Malina \& Bouchard, 1991). The rises in z-scores for stature and BMI relative to the reference data at 9 and 10 years of age (Figure I) almost certainly reflect entrance into these periadolescent events earlier than the national data so that the zscores rise abruptly. The same pattern is seen for mean stature z-scores in girls. Most of the relative population stature advantage is lost in the oldest age groups, where the American Indian children are only slightly taller as young adults than the national norms. This is the expected pattern if the tallness were due to relatively advanced somatic maturation. Unfortunately, we are not aware of any contemporary data available for American Indians concerning the timing of adolescent events such as secondary sex characteristics or menarche that could conclusively confirm this finding.

It is tempting to view those children considered overweight and obese during the puberty-related increases in prevalences (Figure 2) as misclassified because they are simply early maturing children relative to national averages. Nevertheless, some recent analyses indicate that at the high levels of BMI cut-offs defining overweight and obesity the actual effects of the relative timing of somatic maturation on obesity misclassification is very small, probably clinically unimportant, and typically less than I BMI unit (Himes et al., 2009).

Although the biological etiology of the stature-BMI association may be unclear, it is clear that a strong positive association exists. Longitudinal analyses in other children indicate that such tallness-for-age in childhood is predictive of increased likelihood of being overweight or obese as young adults (Stovitz et al., 2010). The high prevalence of overweight and obesity in American Indian adults is well established, as are high burdens of obesity-related sequelae such as type 2 diabetes mellitus and cardiovascular disease (Story et al., 2003; Compher, 2006).

During the childhood years the BMI associations with stature are sufficient that even children approximately one standard deviation taller than the national average $\approx 85^{\text {th }}$ percentile) have a four-fold risk of being overweight or obese compared to the shortest children. At the highest levels of stature-for-age the odds ratio for risk for overweight is I I.5 and I 5.5 for obesity. These dramatic associations should alert health professionals of the current and future risks for tall American Indian children. The clinical notion held by 
some that tall children will outgrow their overweight or obesity is just not supported by the evidence.

\section{REFERENCES}

Compher, C., 2006, The nutrition transition in American Indians. Journal of Transcultural Nursing, 17, pp. 217-223.

Cole, T.J., 1991, Weight-stature indices to measure underweight, overweight, and obesity. In Anthropometric Assessment of Nutritional Status, New York, edited by Himes, J.H., (New York:Wiley-Liss, Inc.); pp. 83-III.

Eveleth, P.B. and Tanner, J.M. 1990, Worldwide Variation in Human Growth. 2nd Ed. (Cambridge England, New York: Cambridge University Press).

Freedman, D.S., Thornton, J.C., Mei, Z., Wang, J., Dietz, W.H., Pierson, R.N. Jr. and Horlick, M., 2004, Height and adiposity among children. Obesity Research, I 2, pp. 846-853.

Haas, J.D. and Campirano, F., 2006, Interpopulation variation in height among children 7 to 18 years of age. Food and Nutrition Bulletin, 27, pp. S2 1 2-S223.

Himes, J.H. and Roche, A.F., 1986, Subcutaneous fatness and stature: relationships from infancy to adulthood. Human Biology, 58, pp. 737-750.

Himes, J.H., Park, K. and Styne, D., 2009, Menarche and assessment of body mass index in adolescent girls. Journal of Pediatrics, I55, pp. 393-397.

Krebs, N.F., Himes, J.H., Jacobson, D., Nicklas,T.A., Guilday, P. and Styne, D., 2007, Assessment of child and adolescent overweight and obesity. Pediatrics, 120, pp. S193-S228.

Kuczmarski, R.J., Ogden, C.L., Guo, S.S., Grummer-Strawn, L.M., Flegal, K.M., Mei, Z., Wei, R., Curtin, L.R., Roche, A.F. and Johnson, C.L., 2000, CDC Growth Charts: United States. Advance Data ,No. 314, pp. I-27.

Lohman, T.G., Roche, A.F. and Martorell, R. (editors), 1988, Anthropometric Standardization Reference Manual, (Champaign, IL: Human Kinetics Books).

Malina, R.M. and Bouchard, C., 199I, Growth, Maturation, and Physical Activity. (Champaign, IL: Human Kinetics Books).

Story, M., Stevens, J., Himes, J.H., Stone, E., Holy Rock, B., Ethelbah, B. and Davis, S., 2003, Obesity in American-Indian children: prevalence, consequences, and prevention. Preventive Medicine, 37, pp. S3-SI2.

Stovitz, S.D., Pereira, M.A., Vazquez, G., Lytle, L.A. and Himes, J.H., 2008, The interaction of childhood height and childhood BMI in the prediction of young adult BMI. Obesity, I 6, pp. 2336-234l.

Stovitz, S.D., Hannan, P.J., Lytle, L.A., Demerath, E.W., Pereira, M.A. and Himes, J.H. 20I0, Child height and the risk of young-adult obesity. American Journal of Preventive Medicine, 38, pp. 74-77.

Sullivan, L.R., 1920, Anthropometry of the Siouan Tribes. Proceedings of the National Academy of Sciences of the United States of America, 6, pp. I 31 - 134.

Wissler, C., 1911, Measurements of Dakota Indian children. Annals of the New York Academy of Sciences, 20, pp. 355-364 
Zephier, E., Himes, J.H., Story, M. and Zhou, X., 2006, Increasing prevalences of overweight and obesity in Northern Plains American Indian children. Archives of Pediatrics \& Adolescent Medicine, I60, pp. 34-39. 